\title{
Transmission of HIV-1 infection by oroanal intercourse
}

\author{
S K Gill, C Loveday, R J C Gilson
}

\begin{abstract}
We report the cases of two homosexual men, one of whom is believed to have been infected with HIV-1 during oroanal intercourse with the other, his only current sexual partner. Both patients had seroconversion illnesses with similar symptoms and signs, and of similar duration. The practise of oroanal intercourse is known to be associated with the transmission of enteric infections and has been implicated in the epidemiology of Kaposi's sarcoma. These well-documented cases indicate that HIV-1 may also be transmitted by this route and supports a cautious approach to recommendations regarding "safer" sex.
\end{abstract}

\section{Introduction}

The epidemic of HIV-1 infection among homosexual men has led to marked changes in sexual behaviour in this population. ${ }^{1} \mathrm{~A}$ decline has been reported in the proportion of homosexual men practising active and passive penetrative anal intercourse associated with a change to alternative, "safer" sexual practices. $^{2}$

There have, however, been reports of the transmission of HIV-1 by "safer sex" practices, notably transmission by orogenital sex which has led to concern regarding the recommendations for "safer sex" practices. ${ }^{3-8}$ Another such practice, that of oroanal intercourse ("rimming") is known to be associated with the transmission of infections in homosexual men, including hepatitis A virus, ${ }^{9}$ Neisseria meningitidis $^{10}$ and Neisseria gonorrhoeae, ${ }^{11}$ Giardia lamblia, Shigella sp. and Entamoeba histolytica. ${ }^{12}$ Further, there has been a proposed link between a possible infectious agent transmitted by this sexual practice, and the epidemiology of Kaposi's sarcoma. ${ }^{1314}$ However, to date there have been no reports of transmission of HIV-1 infection by oroanal intercourse. We report here the cases of two homosexual men who seroconverted for anti-HIV-1 in which the index case, having acquired HIV-1 by unprotected anal intercourse with another partner, then infected his regular partner during oroanal intercourse.

\section{Materials, methods and cases}

The index case (Case 1) was participating, as a control, in a cohort study of homosexual men at risk of HIV-1 infection (being anti-HIV-1 negative and with a history of multiple sexual partners). ${ }^{15}$ Subjects were interviewed 3-monthly with a general medical and behavioural questionnaire which included a detailed sexual history. The second case (Case 2) was recruited to the cohort study following the seroconversion of the index case, as the sexual partner of a known HIV-1-seropositive individual. Blood was taken at each attendance and serum stored at $-20^{\circ} \mathrm{C}$.

\section{Laboratory methods}

Serum samples were tested at each visit to detect anti-HIV-1 antibodies using a competitive enzyme-linked immunosorbent assay (Wellcozyme HIV Recombinant, Wellcome Diagnostics). Further investigation of antiHIV-1 seroconversion was performed on serial samples using three supplementary, divergent assays: an antiglobulin assay (Abbott Laboratories), a gelatin particle agglutination assay (Serodia-HIV, Fujirebio Inc) and Western blot (Dupont Ltd), all according to manufacturers' instructions. In addition, serum p24 and reverse transcriptase (RT) antigens were measured, using in-house assays. ${ }^{16}$ Briefly, the p24 antigen assay consisted of incubating serum samples overnight at $37^{\circ} \mathrm{C}$ in microtitre wells coated with purified gammaglobulin fraction from a high titre anti-p24-positive human serum. After washing, wells were incubated with a rabbit antiserum to recombinant p24 antigen (Wellcome Research Laboratories) and bound antiserum was then detected using horseradish peroxidase-conjugated swine antirabbit IgG.

The RT antigen assay was based upon the same principle except bound antibody was detected using alkaline phosphatase-conjugated goat anti-rabbit IgG and RT demonstrated using a substrate-amplifier system. In both assays, dilutions of p24 and RT antigens in normal human serum were included in each run. Results were expressed in $\mathrm{pg} / \mathrm{ml}$ for values above a cut-off ( 3 SD from the mean of the negative: $7.5 \mathrm{pg} / \mathrm{ml}$ in the $\mathrm{p} 24$ assay and $10 \mathrm{pg} /$ $\mathrm{ml}$ in the RT assay) and showing greater than $50 \%$ neutralisation with a reference anti-p24 or anti-RT serum in a paired well for every sample.

Case 1

The index case (Case 1) was a 28 year old man, enroled into the cohort in 1986 . He had attended regularly at 3-monthly intervals and on each occasion was anti-HIV-1 negative. In March 1988, 6 weeks following passive unprotected anal intercourse with a casual partner, he presented with a one week history of widespread maculopapular rash, generalised lymphadenopathy, marked tonsillar enlarge- 


\begin{tabular}{|c|c|c|c|c|c|c|c|c|c|c|}
\hline \multirow{2}{*}{$\begin{array}{l}\text { CASE } 1 \\
\text { Date }\end{array}$} & \multirow[b]{2}{*}{17.12 .87} & \multicolumn{2}{|c|}{ ILLNESS } & \multirow[b]{2}{*}{11.4 .88} & \multirow[b]{2}{*}{1.6 .88} & \multirow[b]{2}{*}{1.9 .88} & \multirow[b]{2}{*}{2.12 .88} & \multirow[b]{2}{*}{ 3.3.89 } & \multirow[b]{2}{*}{12.10 .89} & \multirow[b]{2}{*}{2.2 .90} \\
\hline & & 10.3 .88 & 21.3 .88 & & & & & & & \\
\hline $\begin{array}{l}\text { Wellcome } \\
\text { Competitive } \\
\text { anti-HIV-1 }\end{array}$ & $\begin{array}{l}\text { NEG } \\
(0.15)\end{array}$ & $\begin{array}{l}\text { NEG } \\
(0.57)\end{array}$ & $\begin{array}{l}\text { POS } \\
(1.07)\end{array}$ & $\begin{array}{l}\text { POS } \\
(3.81)\end{array}$ & $\begin{array}{c}\text { POS } \\
(12 \cdot 3)\end{array}$ & $\begin{array}{l}\text { POS } \\
(21.4)\end{array}$ & $\begin{array}{l}\text { POS } \\
(22.3)\end{array}$ & ND & ND & ND \\
\hline $\begin{array}{l}\text { Abbott } \\
\text { anti-globulin } \\
\text { anti-HIV-1 }\end{array}$ & ND & $\begin{array}{l}\text { NEG } \\
(0.12)\end{array}$ & $\begin{array}{l}\text { NEG } \\
(0.53)\end{array}$ & $\begin{array}{l}\text { POS } \\
(1.77)\end{array}$ & ND & ND & ND & ND & ND & ND \\
\hline $\begin{array}{l}\text { Fujirebio } \\
\text { PAA }\end{array}$ & ND & $\begin{array}{c}\text { NEG } \\
(<1 / 16)\end{array}$ & ND & $\begin{array}{c}\text { POS } \\
(>1 / 256)\end{array}$ & ND & ND & ND & ND & ND & ND \\
\hline Western Blot & NEG & NEG & NEG & NEG & POS & POS & ND & ND & ND & ND \\
\hline p24 Ag (pg/ml) & NEG & 10 & NEG & NEG & NEG & NEG & 271 & 367 & 338 & 944 \\
\hline RT Ag (pg/ml) & NEG & 72 & 36 & NEG & NEG & NEG & NEG & NEG & NEG & NEG \\
\hline
\end{tabular}

\begin{tabular}{|c|c|c|c|c|c|c|c|c|}
\hline \multirow{2}{*}{$\begin{array}{l}\text { CASE } 2 \\
\text { Date }\end{array}$} & \multirow[b]{2}{*}{14.10 .88} & \multicolumn{4}{|c|}{ ILLNESS } & \multirow[b]{2}{*}{ 26.9.89 } & \multirow[b]{2}{*}{ 2.2.90 } & \multirow[b]{2}{*}{5.9 .90} \\
\hline & & 30.1 .89 & 3.2 .89 & 9.2 .89 & 14.2 .89 & & & \\
\hline $\begin{array}{l}\text { Wellcome } \\
\text { Competitive } \\
\text { anti-HIV-1 }\end{array}$ & $\begin{array}{l}\text { NEG } \\
(0.10)\end{array}$ & $\begin{array}{l}\text { NEG } \\
(0.45)\end{array}$ & $\begin{array}{l}\text { NEG } \\
(0.43)\end{array}$ & $\begin{array}{l}\text { NEG } \\
(0.98)\end{array}$ & $\begin{array}{c}\text { POS } \\
(1.15)\end{array}$ & $\begin{array}{c}\text { POS } \\
(21 \cdot 4)\end{array}$ & $\begin{array}{l}\text { POS } \\
(24.2)\end{array}$ & $\begin{array}{c}\text { POS } \\
(25 \cdot 1)\end{array}$ \\
\hline $\begin{array}{l}\text { Abbott } \\
\text { anti-globulin } \\
\text { anti-HIV-1 }\end{array}$ & ND & $\begin{array}{l}\text { NEG } \\
(0.3)\end{array}$ & $\begin{array}{l}\text { NEG } \\
(0.21)\end{array}$ & $\begin{array}{l}\text { POS } \\
(1.03)\end{array}$ & $\begin{array}{l}\text { POS } \\
(1.64)\end{array}$ & $\begin{array}{c}\text { POS } \\
(16.5)\end{array}$ & ND & ND \\
\hline $\begin{array}{l}\text { Fujirebio } \\
\text { PAA }\end{array}$ & ND & $\begin{array}{c}\text { NEG } \\
(<1 / 16)\end{array}$ & $\begin{array}{c}\text { NEG } \\
(<1 / 16)\end{array}$ & ND & $\begin{array}{l}\text { POS } \\
(1 / 128)\end{array}$ & $\underset{(>1 / 256)}{\text { POS }}$ & ND & ND \\
\hline Western Blot & NEG & NEG & NEG & NEG & NEG & POS & POS & ND \\
\hline p24 Ag (pg/ml) & NEG & 15 & 8 & 8 & NEG & NEG & NEG & NEG \\
\hline RT Ag (pg/ml) & NEG & 12 & 35 & 30 & NEG & NEG & NEG & NEG \\
\hline
\end{tabular}

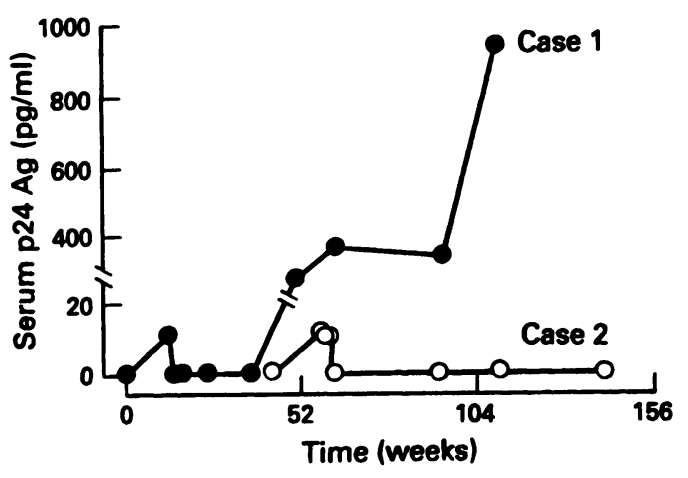

ment and petechiae over his shins. Serum collected at presentation contained p24 antigen and RT antigen but anti-HIV-1 antibodies were not detectable. Seroconversion for antiHIV-1 was confirmed four weeks later, when p24 antigen was no longer detectable (fig). In December 1988, nine months after his HIV-1 seroconversion illness, the index patient remained clinically well apart from persistent gingivitis; however, serum p24 antigen was detectable at $271 \mathrm{pg} / \mathrm{ml}$ and his CD4 count was low at $210 \times 10^{6} / 1$.

Case 2

After the seroconversion of the index patient, his sexual partner of five years was counselled in May 1988 regarding safe sex practices. Their last episode of anal intercourse had been four months previously and he denied any other sexual contacts. Anti-HIV-1 serology was neg-
Figure Serological events before, during and after anti-HIV-1 seroconversion in both cases. The box indicates the symptomatic period. Figures in brackets for the Wellcome and Abbott anti-HIV-l assays are normalised optical densities (the ratio of the test cut-off to the patient's signal; $<1=$ negative, $>1=$ positive) and for the Fujirebio assay the highest dilution of serum producing particle agglutination. Western blot results were defined according to the manufacturer's criteria. P24 and RT antigens are expressed in $\mathrm{pg} / \mathrm{ml}$ of serum with test cut-off being 7.5 and $10 \mathrm{pg} / \mathrm{ml}$ respectively. The graph shows serial p24 antigen measurements in both cases. $A$ brief, low level antigenaemia is associated with the

seroconversion illness. In Case 1 (closed circles) persistent, high level antigenaemia developed 9 months after primary infection, corresponding to the time of infection of Case 2 (open circles). ND = test not done.

ative and he was reviewed at 3-monthly intervals.

In January 1989, he presented with symptoms very similar to the HIV-1 seroconversion illness of the index case: widespread skin rash, tonsillar enlargement, lymphadenopathy and petechiae. Serum p24 antigen and RT antigen were detectable and anti-HIV-1 antibodies became detectable two weeks later (fig).

Careful questioning of both partners independently, revealed that the only recent intimate contact which they each described, was an episode of oroanal intercourse in which the index case was insertive with his tongue. This had taken place three weeks prior to the seroconversion illness of Case 2. They had had no other sexual contact for at least 3 months prior to this, and the last episode of orogenital or anal intercourse had taken place at least 1 year previously and more than three months 
prior to the seroconversion of the index case as described above. The partner denied any other sexual contacts.

\section{Discussion}

We report the cases of two homosexual men in which one partner was apparently infected with HIV-1 during oroanal intercourse, based on careful history-taking from both partners. The two patients were participating in a prospective cohort study, were seen regularly by the same physician and had not previously been suspected of failure to disclose details of their sexual histories. We therefore believe it to be unlikely that the partner acquired HIV-1 infection as a result of unprotected genital intercourse with the index case, or as a result of intercourse with another partner.

Epidemiological studies of HIV-I infection amongst homosexual men have not shown that oroanal intercourse is a risk factor for transmission. The risk associated would, however, be expected to be much less than that of unprotected anal intercourse. In such studies, few subjects would have engaged exclusively in "safer" sexual practices, and any associations would be unlikely to be detectable when higher risk activities predominate.

The partner, Case 2, seroconverted for antiHIV-1 at a time when the index case had gingivitis, persistent p24 antigenaemia and a low CD4 count This was 9 months after the seroconversion illness of the index case. Others have reported the early development of these markers of disease progression to be associated with a prolonged seroconversion illness. ${ }^{17}$ Detectable p24-antigenaemia is associated with high levels of plasma viraemia ${ }^{18}$ and the index case may therefore have been highly infectious. A low CD4-count and p24-antigenaemia have been associated with increased rates of transmission. ${ }^{19}$ It is suggested here that the similarity of the seroconversion illnesses of the two patients is consistent with their being infected with the same strain of HIV-1. No work has yet demonstrated that the clinical features of HIV-1 seroconversion and the subsequent infection are determined by the strain of virus, and to date we have not isolated and compared the viral genomic sequences implicated in this transmission event.

The mechanism of transmission by oroanal intercourse is a matter for speculation; however, its plausibility is supported by evidence for the presence of HIV-1 in saliva. ${ }^{20}$ The infectivity of the index case reported here may have been increased by the gingivitis which is associated with bleeding, and by high levels of viraemia. Recently it has been suggested that the dendritic cells of the reticuloendothelial system (CD4 positive, phagocytic, and antigen presenting cells) in the gut are susceptible to infection and serve as the primary target for HIV-1 infection, prior to presentation to lymphocytes in lymph nodes. ${ }^{21}$ Such a mechanism would help to explain the feasibility of this mode of transmission even through intact mucosa. Alternatively, other organisms could act as vectors for HIV-1 transmission although this is more likely for the anus-to-mouth route than mouth-to-anus as postulated here. Viruses have been observed within protozoa including $E$. histolytica and $G$. lamblia. ${ }^{22}$ In vitro studies have shown uptake of HIV-1 by $E$. histolytica when co-cultured with HUT-78 cell lines chronically infected with the SF33 laboratory strain of HIV-1. ${ }^{23}$ Onward transmission to peripheral blood mononuclear cells however was not demonstrated.

While oroanal intercourse or "rimming" is known to be associated with the transmission of other infections, we report evidence that HIV-1 infection may be transmitted by this sexual practice. Although this may be rare and the index case reported here may have been of exceptionally high infectivity, this should be considered when patients are counselled regarding safer sexual practices. The use of condoms during fellatio should continue to be promoted. The use of dental dams may be less widely recognised. These sheets of latex can be effectively used during orogenital, including oroanal contact although care should be exercised to ensure that they are not inadvertently reversed during use, for example by marking one side.

Dr Gill and the cohort studies were supported by a grant from the Medical Research Council.

1 Carne CA, Weller IVD, Johnson AM, et al. Prevalence of antibodies to human immunodeficiency virus, gonorantibodies to human immunodeficiency virus, gonormen in London. Lancet 1987;1:656-8

2 Johnson AM, Gill ON. Evidence for recent changes in sexual behaviour in homosexual men in England and Wales. Phil Trans $R$ Soc Lond 1989;325:153-61.

3 Rozenbaum W, Gharakhanian S, Cardon B, Duval E, Coulaud JP. HIV transmission by oral sex. Lancet 1988;i:1395.

4 Goldberg DJ, Green ST, Kennedy DH, Emslie JAN, Black ID. HIV and orogenital transmission. Lancet 1988 ii: 1363 .

5 Quarto M, Germinario C, Troiano A, Fontana A, Barbuti S HIV transmission by fellatio. Eur $\mathcal{f}$ Epidemiol 1990 6:339-40.

6 Spitzer PG, Weiner NJ. Transmission of HIV infection from a woman to a man by oral sex. $N$ Engl $\Im$ Med 1990 320:251.

7 Lifson AR, O'Malley PM, Hessol NA, Buchbinder SP, Cannon L, Rutherford GW. HIV seroconversion in two homosexual men after receptive oral intercourse with ejaculation: implications for counselling concerning safe sex practices. Am $\mathcal{F}$ Public Health 1990;80:1509-11.

8 Murray AB, Greenhouse PRDH, Nelson WLC, Norman JE, Jeffries DJ, Anderson J. Coincident acquisition of Neisseria gonorrhoeae and HIV from fellatio. Lancet 1991; 338:830.

9 Corey L, Holmes KK. Sexual transmission of hepatitis A in homosexual men. Incidence and mechanism. $N$ Engl $\mathcal{f}$ Med 1980;302:435-8.

10 Judson FN, Ehret JM, Eickhoff TC. Anogenital infection with Neisseria meningitidis in homosexual men. $\mathcal{F}$ Infect Dis 1978;137:458-63.

11 Tomlinson DR, French PD, Harris JRW, Mercey DE. Does rectal gonorrhoea reflect unsafe sex? Lancet 1991; 337.501-2.

12 Dritz SK, Ainsworth TE, Garrard WF, et al. Patterns of sexually transmitted enteric diseases in a city. Lancet 1977;ii:3-4.

13 Beral V, Peterman TA, Berkelman RL, Jaffe HW. Kaposi's sarcoma among persons with AIDS: a sexually transmitted infection? Lancet 1990;335:123-8.

14 Abrams DI. The relationship between Kaposi's sarcoma and intestinal parasites among homosexual males in the United States. I Acq Immun Defic Syndr 1990; 3:S44-S46.

15 Kelly GE, Stanley BS, Weller IVD. The natural history of human immunodeficiency virus infection: a five year human immunodeficiency Med 1990;66:238-43.

16 Loveday C, Williams H, Tedder RS. An ELISA assay for the measurement of HIVI RT antigen. Sixth International measurement of HIVI RT antigen. Sixth International 329.

17 Pedersen C, Lindhardt BO, Jensen BL, et al. Clinical course of primary HIV infection: consequences for subsequent of primary HIV infection: consequences for
course of infection. $B M \Im$ 1989;299:154-7. 
18 Semple M, Loveday C, Weller I, Tedder R. Direct measurement of viraemia in patients infected with HIV-1 and its relationship to disease progression and zidovudine therrelationship to disease progression

19 Johnson AM, Laga M. Heterosexual transmission of HIV. AIDS 1988;2:S49-S56.

20 Groopman JE, Salahuddin SZ, Sarngadharan MG, et al. HTLV-III in saliva of people with AIDS-related complex and healthy homosexual men at risk for AIDS. Science 1984;226:447-9.
21 Amerongen HM, Weltzin $R$, Farnet $C M$, Michetti $P$, Haseltine WA, Neutra MR. Transepithelial transport of HIV- 1 by intestinal $M$ cells: a mechanism for transmission of AIDS. F Acq Immun Defic Syndr 1991;4:760-5. 22 Miles MA. Viruses of parasitic protozoa. Parasitology Today 1988;4:289-90.

23. Brown M, Reed S, Levy JA, Busch M, McKerrow JH. Detection of HIV-1 in Entamoeba histolytica without evidence of transmission to human cells. AIDS 1991; 5:93-6. 